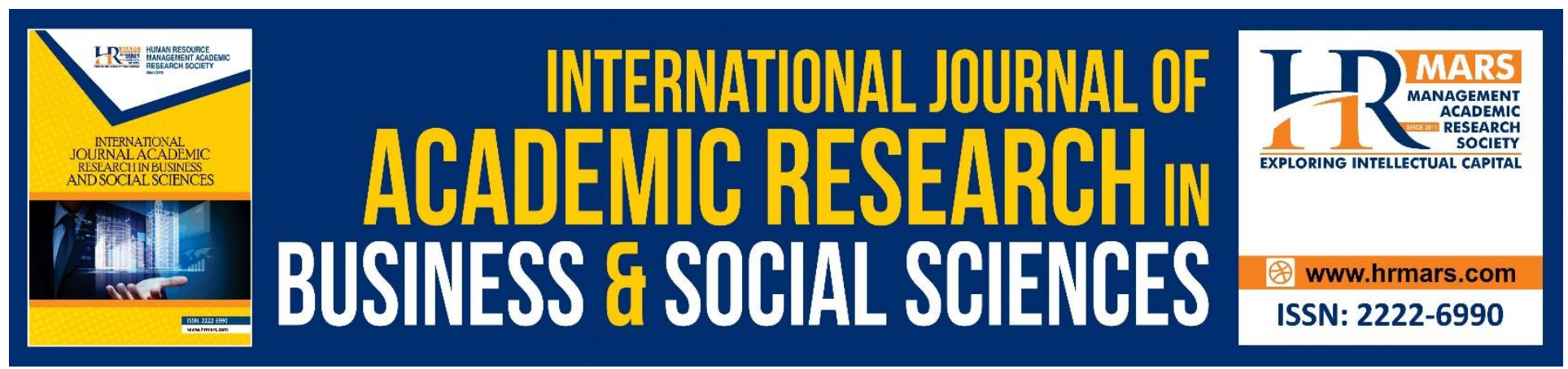

\title{
The Leadership Style among Football Coaches in Iraqi's Public Universities
}

Ismail, E., Razak, M. R. A., Bakar, A. Y. A. \& Mahmood, H. N.

To Link this Article: http://dx.doi.org/10.6007/IJARBSS/v10-i8/7513

DOI:10.6007/IJARBSS/v10-i8/7513

Received: 09 May 2020, Revised: 12 June 2020, Accepted: 22 July 2020

Published Online: 21 August 2020

In-Text Citation: (Ismail et al., 2020)

To Cite this Article: Ismail, E., Razak, M. R. A., Bakar, A. Y. A., \& Mahmood, H. N. (2020). The Leadership Style among Football Coaches in Iraqi's Public Universities. International Journal of Academic Research in Business and Social Sciences, 10(8), 153-161.

Copyright: (C) 2020 The Author(s)

Published by Human Resource Management Academic Research Society (www.hrmars.com)

This article is published under the Creative Commons Attribution (CC BY 4.0) license. Anyone may reproduce, distribute, translate and create derivative works of this article (for both commercial and non-commercial purposes), subject to full attribution to the original publication and authors. The full terms of this license may be seen at: $\underline{\text { http://creativecommons.org/licences/by/4.0/legalcode }}$

Vol. 10, No. 8, 2020, Pg. 153 - 161

http://hrmars.com/index.php/pages/detail/IJARBSS

JOURNAL HOMEPAGE

Full Terms \& Conditions of access and use can be found at http://hrmars.com/index.php/pages/detail/publication-ethics 


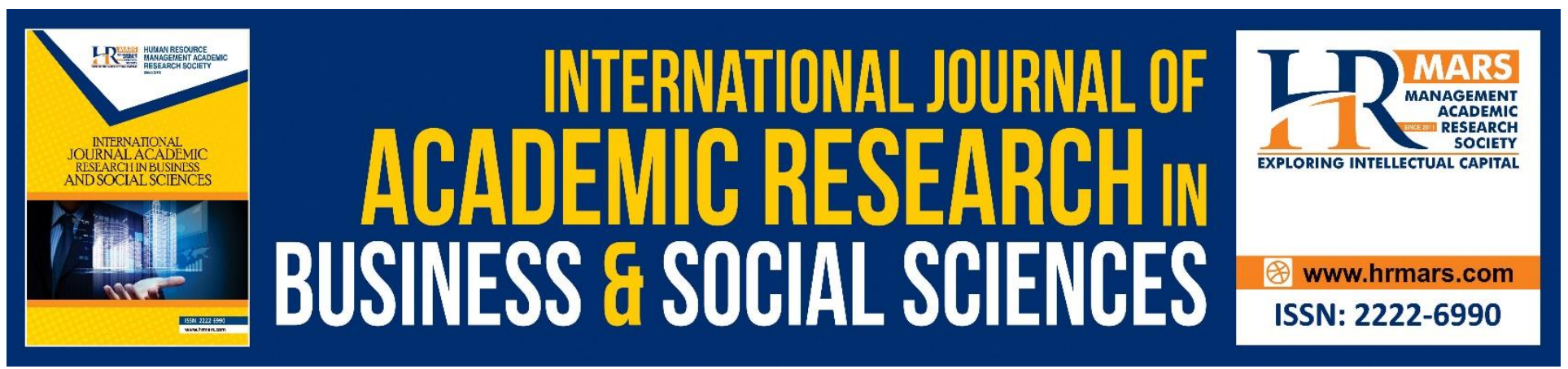

\title{
The Leadership Style among Football Coaches in Iraqi's Public Universities
}

\author{
Ismail, E., Razak, M. R. A., Bakar, A. Y. A. \& Mahmood, H. N. \\ Faculty of Education, Universiti Kebangsaan Malaysia, 43600 Bangi, Selangor, MALAYSIA \\ Email: yazid3338@ukm.edu.my
}

\begin{abstract}
The leadership style is a critical determinant of success in any field of endeavour. The leadership style and athletes' satisfaction are considered as one of the significant factors in the sport fields. The purpose on these studies is the leadership style among coaches and the relationship between football player in Iraqi Public Universities. These researches are using the cross-sectional survey as research design. This study comprised a total of 194 male soccer players from all eleven public Iraqi's universities football teams. The instrument of this research are the Multidimensional Model of Leadership ( $\mathrm{MML}$ ), a model to identify the relationship between five leadership styles (Training \& Instruction, Autocratic Style, Democratic Style, Social Support, and Positive Feedback) and athletes' satisfaction which including two instruments namely Leadership Scale for Sport (LSS), to determine leadership style, and Athlete Satisfaction Questionnaire (ASQ), to examine athletes' satisfaction. The descriptive statistics results show that the most popular Iraqi coaches leadership style among the five basic leadership styles was training and instruction $(M=3.487)$. The results of satisfaction athlete's subscale show that the most popular is personal treatment $(M=5.946)$. There are the relationship between leadership style and athletes' satisfaction where's the team performance has a high relationship between leadership style $(r=.563, p<.05)$. The personal treatment has a high relationship between democratic style $(r=.482, p<.05)$, the training and instruction has a high relationship between leadership style $(r=.655, p<.05)$, and the individual performance has a high relationship between social support $(r=.595, p<.05)$. In the nutshell, the athletes' satisfaction has a high relationship between leadership style $(r=.781, p<.05)$. The findings of this research emphasize the importance of the relationship between the coach leadership styles and the satisfaction of the athletes. A proper leadership style of a coach has a significant positive effect on athletes' satisfaction. In the other words, when the coach has a negative leadership style, it decreases the athletes' satisfaction and the team performance in general.
\end{abstract}

Keywords: Coach, Football, Iraq, Leadership Style, Public University.

\section{Introduction}

Leadership is regarded as underlying factor that impacted on the social interaction process, cohesion of the group, and developing sport operation to the highest possible degree of efficiency, 
INTERNATIONAL JOURNAL OF ACADEMIC RESEARCH IN BUSINESS AND SOCIAL SCIENCES Vol. 10, No. 8, 2020, E-ISSN: 2222-6990 @ 2020 HRMARS

effectiveness, and achievement. Successful leadership can directly affect the style and activity of individuals in realizing the desired goals via positive interaction and communication (Basford et al. 2012).

In sports, the coach is the official leader of the group (Beauchamp \& Eys, 2014; Weinberg \& Gould, 2014). A good sports leader is a coach who provides the appropriate technical preparation for athletes and the team with the support they need and motivate them to implement the vision of victory. The coach, seen as an expert whose mission to lead the athletes, encourage them to realize their full potential, and achieve the best possible results. It is important to emphasize that the coach is responsible, not only for the physical preparation, theoretical methods, and the development of motor coordination, but for the formation of the appropriate level of motivation and practice of educational effect on the racers as well (Wałach-Biśta, 2014).

The leadership styles of coaches are regarded as a critical point of satisfaction in football teams (Saybani et al. 2013). Unsuitable leadership styles of the coaches may lead to stress, lack of harmony, and the failure to achieve the goals of the team. Iraqi university teams do not have a suitable style of coach leadership. Furthermore, coaches are required to possess a range of leadership styles, training, evaluation, and humanity skills that qualify him/her to complete the task correctly. Therefore, by identifying the correct leadership style is expected to improve the performance of the athletes, and subsequently, team.

Excellent communication between athletes and coaches help to deliver beneficial information such as tactics, strategies, and the techniques of the game to his players (Sagar \& Jowett 2012). However, further work are needed to handle the challenges of correlating leadership styles of football coach and the athletes' satisfaction, such as players' mistakes, delivering effective information, and expressing hidden and negative issues. Thus, active and effective correlation between leadership styles of football coach and athletes is necessary towards satisfying the team.

Jannat and Mea (2014) stated that a coach can improve the relationships between themselves and athletes if the coach has a better understanding of the subtle exchange and role relationships, which will help them retain athletes' satisfaction and enjoyment with the sport. Although coaches are vary in terms of personality, qualification, and leadership style, there is no doubt that coaches tremendously impact athletes' psychological and physical welfare (Chelladurai 2012), and their motivation (Dileep 2012). Normally, a coach has a number of roles, which includes a planned, coordinated, and integrated program of athlete preparation (Moen \& Federici 2013).

The football games are games that require high commitment and good coach selection. Therefore, the main objective is to examine the relationship between satisfaction of sports team's soccer athletes on the leadership style of their coaches. The findings of this research emphasize the importance of the relationship between the coach leadership styles and the satisfaction of the athletes. A proper leadership style of a coach has a significant positive effect on athletes' satisfaction. In the other words, when the coach has a negative leadership style, it decreases the athletes' satisfaction and the team performance in general.

\section{Research Objectives}

The objectives in this study are as follows:

i. To identify which type of leadership styles, do Iraqi football coaches adopt regards to Iraqi Universities football player'. 
INTERNATIONAL JOURNAL OF ACADEMIC RESEARCH IN BUSINESS AND SOCIAL SCIENCES Vol. 10, No. 8, 2020, E-ISSN: 2222-6990 @ 2020 HRMARS

ii. To examine the differences of leadership styles of football coach among athletes' satisfaction at Iraqi Universities.

iii. To determine the correlation between leadership styles of football coach and the athletes' satisfaction at Iraqi Universities.

\section{Methodology}

This cross-sectional study is quantitative in nature, and was conducted using the survey methodology. This research was carried out at Iraqi universities; therefore, the population of this study included all the public Iraqi universities. These studies used Krecjie and Morgan (1970) to determine the size sample. The total sample include were 194 football athletes aged between 18 to 26 years old who were also full-time students who come from different universities scattered around Iraq and also males' athletes selected from the athletic rosters in football. Therefore, the researcher is distributed for each university twenty-two questionnaires to get the high response. The Multidimensional Model of Leadership (MML) (Riemer, 2007), Leadership Scale for Sport (LSS) (Zhang, Jensen \& Mann, 1997), and Athlete Satisfaction Questionnaire (ASQ) (Riemer \& Chelladurai, 1998) were selected to investigate leadership style, relationship between leadership style, and athletes' satisfaction. The study sample consists of male footballer hailing from Iraq's public university teams.

\section{Findings}

Based on the descriptive analysis of this study, there were a total of 194 male respondents. The results presented showed 95 (49.0\%) participants were aged between 21 to 23 years, 77 (39.7\%) participants were aged between 18 to 20 years, and 22 (11.3\%) of them were in the age category of 24 to 26 years old. The results showed that the heights of $108(55.7 \%)$ athletes were between 171 to 180 centimetres, 49 (25.3\%) athletes have heights between 160 to 170 centimetres, and 37 (19.1\%) athletes' heights were between 181 to 190 centimetres. Table 1 shows the demographic background analysis among footballer.

Table 1The demographic background analysis

\begin{tabular}{llcc}
\hline & & Frequency & Percentage (\%) \\
\hline Gender & Male & 194 & 100.00 \\
\hline Age & $18-20$ years old & 77 & 39.7 \\
& $21-23$ years old & 95 & 49.0 \\
& $24-26$ years old & 22 & 11.3 \\
\hline Education & Bachelor & 192 & 99.0 \\
& Master & 2 & 1.0 \\
\hline Marital Status & Single & 189 & 97.4 \\
& Married & 5 & 2.6 \\
\hline Height & $160-170 \mathrm{~cm}$ & 49 & 25.3 \\
& $171-180 \mathrm{~cm}$ & 108 & 55.7 \\
& $181-190 \mathrm{~cm}$ & 37 & 19.1 \\
\hline Weight & $55-65 \mathrm{~kg}$ & 4 & 2.1 \\
& $66-75 \mathrm{~kg}$ & 154 & 79.4 \\
& $76-85 \mathrm{~kg}$ & 36 & 18.6 \\
\hline Experience & $2-4$ years & 17 & 8.8 \\
& $5-7$ years & 132 & 68.0 \\
\hline
\end{tabular}


INTERNATIONAL JOURNAL OF ACADEMIC RESEARCH IN BUSINESS AND SOCIAL SCIENCES Vol. 10, No. 8, 2020, E-ISSN: 2222-6990 @ 2020 HRMARS

\begin{tabular}{llcc}
\hline & More than 7 years & 45 & 23.2 \\
\hline Level of Sport & Sport Clubs & 8 & 4.1 \\
& Popular Teams & 186 & 95.9 \\
\hline Year of Study & First & 23 & 11.9 \\
& Second & 57 & 29.4 \\
& Third & 65 & 33.5 \\
& Fourth & 49 & 25.3 \\
\hline \multirow{2}{*}{ Training Time per Week } & $8-10$ hours & 7 & 3.6 \\
& $11-13$ hours & 129 & 66.5 \\
& More than 13 hours & 58 & 29.9 \\
\hline
\end{tabular}

The results of the descriptive statistical analysis showed the leadership style of football coaches adopt the training and instruction style, due to its score of $(M=3.487$ and $S D=1.043)$, followed by social support style with $(M=3.393$ and $S D=1.074)$, and the positive feedback $(M=3.335$ and $S D=1.023)$, the democratic style $(M=3.210$ and $S D=0.891)$, and the autocratic style $(M=2.815$ and $S D=0.981)$. Table 2 shows the analysis of leadership coach style.

Table 2 The descriptive statistics of leadership coach style

\begin{tabular}{cccccc}
\hline \multirow{2}{*}{ Scores } & \multicolumn{5}{c}{ Element } \\
\cline { 2 - 6 } & $\begin{array}{c}\text { Training } \\
\text { and } \\
\text { Instruction }\end{array}$ & $\begin{array}{c}\text { Social } \\
\text { Support }\end{array}$ & $\begin{array}{c}\text { Positive } \\
\text { Feedback }\end{array}$ & $\begin{array}{c}\text { Democratic } \\
\text { style }\end{array}$ & $\begin{array}{c}\text { Autocratic } \\
\text { Style }\end{array}$ \\
\hline Mean & 3.487 & 3.393 & 3.335 & 3.210 & 2.815 \\
SD & 1.043 & 1.074 & 1.023 & 0.891 & 0.981
\end{tabular}

The results of the descriptive statistical analysis showed that the highest mean score of athletes' satisfactions was personal treatment satisfaction with $(M=5.946$ and $S D=0.711)$, followed by Individual performance satisfaction with $(M=5.539$ and $S D=0.886)$, the team performance satisfaction was $(M=5.474$ and $S D=0.718)$, and at the end came Training and Instruction satisfaction with $(M=5.336$ and $S D=1.133)$. Table 3 shows the analysis of the footballer satisfaction subscales.

Table 3 The analysis of the footballer satisfaction subscales

\begin{tabular}{ccccc}
\hline \multirow{2}{*}{ Scores } & \multicolumn{4}{c}{ Element } \\
\cline { 2 - 5 } & $\begin{array}{c}\text { Personal } \\
\text { treatment }\end{array}$ & $\begin{array}{c}\text { Individual } \\
\text { performance }\end{array}$ & $\begin{array}{c}\text { Team } \\
\text { performance }\end{array}$ & $\begin{array}{c}\text { Training and } \\
\text { Instruction }\end{array}$ \\
\hline Mean & 5.946 & 5.539 & 5.474 & 5.336 \\
SD & 0.711 & 0.886 & 0.718 & 1.133
\end{tabular}

The findings show that there is a significant relationship between leadership style and athletes' satisfaction. The team performance has a high relationship between leadership style $(r=.563, p<$ .05). The personal treatment has a high relationship between democratic style $(r=.482, p<.05)$, the training and instruction has a high relationship between leadership style $(r=.655, p<.05)$, and the 
INTERNATIONAL JOURNAL OF ACADEMIC RESEARCH IN BUSINESS AND SOCIAL SCIENCES

Vol. 10, No. 8, 2020, E-ISSN: 2222-6990 @ 2020 HRMARS

individual performance has a high relationship between social support $(r=.595, p<.05)$. In the nutshell, the athletes' satisfaction has a high relationship between leadership style $(r=.781, p<.05)$. Table 4 shows the analysis of relationship between leadership style of coach and athletes' satisfaction.

Table 4The relationship between leadership style of coach and athletes' satisfaction $(N=194)$

\begin{tabular}{|c|c|c|c|c|c|c|c|}
\hline & & $\begin{array}{c}\text { Training } \\
\text { and } \\
\text { instructio } \\
\mathrm{n}\end{array}$ & $\begin{array}{c}\text { Autocrati } \\
\text { c } \\
\text { style }\end{array}$ & $\begin{array}{c}\text { Democrati } \\
\text { c } \\
\text { Style }\end{array}$ & $\begin{array}{c}\text { Social } \\
\text { Suppor } \\
t\end{array}$ & $\begin{array}{c}\text { Positive } \\
\text { Feedbac } \\
\text { k }\end{array}$ & $\begin{array}{c}\text { Leadershi } \\
\text { p } \\
\text { styles }\end{array}$ \\
\hline $\begin{array}{c}\text { Team } \\
\text { performanc } \\
\text { e }\end{array}$ & $\begin{array}{c}\text { Pearson } \\
\text { Correlatio } \\
\text { n } \\
\text { Sig. (2- } \\
\text { tailed) }\end{array}$ & $\begin{array}{c}0.538^{*} \\
.001\end{array}$ & $\begin{array}{c}0.382^{*} \\
.001\end{array}$ & $\begin{array}{c}0.406^{*} \\
.001\end{array}$ & $\begin{array}{c}0.558 * \\
.001\end{array}$ & $\begin{array}{c}0.435^{*} \\
.001\end{array}$ & $\begin{array}{c}0.563^{*} \\
.001\end{array}$ \\
\hline $\begin{array}{l}\text { Personal } \\
\text { treatment }\end{array}$ & $\begin{array}{c}\text { Pearson } \\
\text { Correlatio } \\
n\end{array}$ & $\begin{array}{c}0.402^{*} \\
.001\end{array}$ & $\begin{array}{c}0.185^{*} \\
.001\end{array}$ & $\begin{array}{c}0.482 * \\
.001\end{array}$ & $\begin{array}{c}0.366^{*} \\
.001\end{array}$ & $\begin{array}{c}0.361^{*} \\
.001\end{array}$ & $\begin{array}{c}0.431^{*} \\
.001\end{array}$ \\
\hline
\end{tabular}

Sig. (2-

tailed)

\begin{tabular}{cccccccc}
\hline Training and & Pearson & $0.650^{*}$ & $0.209 *$ & $0.577^{*}$ & $0.616^{*}$ & $0.649 *$ & $0.655^{*}$ \\
instruction & $\begin{array}{c}\text { Correlatio } \\
\mathrm{n}\end{array}$ & .001 & .001 & .001 & .001 & .001 & .001
\end{tabular}

Sig. (2-

tailed)

\begin{tabular}{cccccccc}
\hline Individual & Pearson & $0.517^{*}$ & $0.286^{*}$ & $0.513^{*}$ & $0.595^{*}$ & $0.469 *$ & $0.576^{*}$ \\
performanc & Correlatio & .001 & .001 & .001 & .001 & .001 & .001
\end{tabular}

e

$\mathrm{n}$

Sig. (2-

tailed)

\begin{tabular}{cccccccc}
\hline Athletes' & Pearson & $0.742^{*}$ & $0.357^{*}$ & $0.693 *$ & $0.750^{*}$ & $0.684^{*}$ & $0.781^{*}$ \\
satisfaction & Correlatio & .001 & .001 & .001 & .001 & .001 & .001
\end{tabular}

$\mathrm{n}$

Sig. (2-

tailed)

* Correlation is significant at the 0.05 level

\section{Conclusions}

Leadership is the one of the most extensively studied topics in science and organizational psychology. Many leadership models have been proposed and tested, and interest and activity in the field continues to grow. Coaching styles are unpredictable, and it influences both athletic performance and satisfaction. The dynamics of domain sports encouraged frequent and intense interactions between coaches and athletes (Chang 2008; Altahayneh 2016). This interaction between the coaches 
and athletes has been actively researched in the field of behavioural coaching and leadership style (Chia et al. 2015).

Successful sports teams demonstrate a prominent feature that distinguishes it from its unsuccessful counterparts, which is an effective, active, and qualified management and leadership. Leadership style and coaching feedback played a significant role in the performance and success of a team (Abedini et al. 2014). Coach is the most important elements that affect the efficiency or the success of the teams, since in clubs and sports teams, especially in football, a coach determines the fate of the team and train them to win.

In this research, the actual leadership style of coach evaluated from footballers. Analysis the questionnaire results that distributed to football players universities teams indicated to the training and instruction was the most style is using by coaches. The finding of present study showed the type of leadership styles adopted by coaches was similar findings have been reported in other studies that focused at actual leadership style and studiers that presented the actual leadership styles of coaches according to the perspective of athletes (Jaber 2012; Turksoy et al. 2013; Chiu et al. 2016).

The statistical results in the previous chapter indicated that there is a significantly moderate positive relationship between the leadership style of coaches (social support, training and instruction, democratic style, and positive feedback) and athletes' satisfaction (team performance, personal treatment, training and teaching, and individual performance) and leadership style (autocratic style) and athletes' satisfaction (team performance). The findings of this study that related to leadership styles and athletes' satisfaction subscales are conformed to findings of Andrew (2016) and Altahayneh (2016) where they believed there is a positive relationship between leadership styles and athletes' satisfaction. While the finding of the study is not conformed to the findings of Khalaj et al. (2011) and Ignacio III et al. (2017).

The theoretical contribution of this research is the addition to the current literature through the presentation of hypotheses and relationship between the leadership styles of coaches and satisfaction of athletes, via examination of the differences among coaches' styles and athletes' satisfaction. On the contrary, the contextual contribution of this research is the initial development of services and sports programs at colleges and universities, whereby knowledge pertaining to leadership styles would help coaches create a good relationship with players and improve the performance of the team. The study proved that coaches in Iraq are skilful in utilizing leadership styles to satisfy players and enhance team performance.

Based on the findings of this study, the following recommendations are made the study specified the leadership style of coaches and athlete's satisfaction in universities football teams and the study can be expanded to test other relationships that connect players with other members of the sports organization such as assistant coaches, and medical staff as these relations can play an equally important role in dynamics of coach-athlete relationship.

\section{References}

Abedini, M., Esmaili, M., \& Tojari, F. (2014). The relationship between coaching leadership styles and achievement motivation of Iran's professional and amateurish fencers. International Journal of Sport Studies, 4(7), 744-750.

Altahayneh, Z. L. (2016). Effects of Coaches' Behaviors and Burnout on the Satisfaction and Burnout of Athletes. Degree of Doctor of Philosophy Florida State University, FSU Digital Library. 
INTERNATIONAL JOURNAL OF ACADEMIC RESEARCH IN BUSINESS AND SOCIAL SCIENCES

Vol. 10, No. 8, 2020, E-ISSN: 2222-6990 @ 2020 HRMARS

Andrew, D. P. S. (2016). Effect of Congruence of Leadership Behaviors on Motivation, Commitment, and Satisfaction of College Tennis Players. Tesis Degree of Doctor of Philosophy Florida State University, FSU Digital Library.

Basford, T. E., Offermann, L. R., \& Wirtz, P. W. (2012). Considering the source: The impact of leadership level on follower motivation and intent to stay. Journal of Leadership \& Organizational Studies, 19(2), 202-214.

Beauchamp, M. R., \& Eys, M. A. (Eds.). (2014). Group dynamics in exercise and sport psychology. Routledge.

Chang, K. H. (2008). A study on the influence of coach's leadership behavioral styles and organizational commitment on athlete's satisfaction of college track and field athletes in Taiwan. Ed.: ProQuest.

Chelladurai, P. (2012). Leadership and manifestations of Sport. DIm. S. Murphy (pnyt.). Ed. The Oxford handbook of sport and performance psychology. New York: Oxford University Press, 328-341.

Chia, J. S., Pyun, D. Y., \& Kwon, H. H. (2015). The impact of congruence between perceived and preferred leadership on satisfaction among college student-athletes in Singapore. Asia Pacific Journal of Education, 35(4), 498-513.

Chiu, W., Rodriguez, F. M., \& Won, D. (2016). Revisiting the leadership scale for sport: Examining factor structure through exploratory structural equation modeling. Psychological Reports, 119(2), 435-449.

Dileep. (2012). Does Transformational Leadership Matters? International Journal of Business and Behavioral Sciences, 2(4).

Ignacio, III, R. A., Montecalbo-Ignacio, R. C., \& Cardenas, R. C. (2017). The relationship between perceived coach leadership behaviors and athletes satisfaction. International Journal of Sports Science, 7(5), 196-202.

Jaber, R. R. (2012). Leadership Behavior to Coach Basketball in the Governorates of the Gaza StripPalestine. Journal of Educational \& Psychological Sciences, 13(04).

Jannat, R. N., \& Mea, K. K. (2014). Influence of playing experience and coaching education on coaching efficacy among malaysian youth coaches. Age (Years), 30(50), 15-5.

Khalaj, G., Khabiri, M., \& Sajjadi, N. (2011). The relationship between coaches leadership styles \& player satisfaction in women skate championship. Procedia-Social and Behavioral Sciences, 15, 3596-3601.

Krejcie, R. V., \& Morgan, D. W. (1970). Determining sample size for research activities. Educational and psychological measurement, 30(3), 607-610.

Moen, F., \& Federici, R. A. (2013). Coaches' Coaching Competence in Relation to Athletes' Perceived Progress in Elite Sport. Journal of Education and Learning, 2(1), 240-252.

Riemer, H. A. (2007). Multidimensional model of coach leadership.

Riemer, H. A., \& Chelladurai, P. (1998). Development of the athlete satisfaction questionnaire (ASQ). Journal of sport and exercise psychology, 20(2), 127-156.

Sagar, S. S., \& Jowett, S. (2012). Communicative acts in coach-athlete interactions: When losing competitions and when making mistakes in training. Western Journal of Communication, 76(2), 148-174. 
INTERNATIONAL JOURNAL OF ACADEMIC RESEARCH IN BUSINESS AND SOCIAL SCIENCES

Vol. 10, No. 8, 2020, E-ISSN: 2222-6990 @ 2020 HRMARS

Saybani, H., Yusof, A., Soon, C., Hassan, A., \& Zardoshtian, S. (2013). Athletes' satisfaction as mediator of transformational leadership behaviors of coaches and football players' sport commitment relationship. World Applied Sciences Journal, 21(10), 1475-1483.

Türksoy, A., Ozturk, M., Ataman Yancı, H. B., \& Karalınoglu, D. (2013). Leadership and satisfaction of the Turkish young national football team players. Iıb International Refereed Academic Social Sciences Journal, 4(10), 110-119.

Walach-Bista, Z. (2014). Leadership Scale for Sports-theoretical background and review of psychometric properties research. Česká kinantropologie, 18 (3), 67-76.

Weinberg, R. S., \& Gould, D. (2014). Foundations of Sport and Exercise Psychology Ed. 6th Edition. Human Kinetics.

Zhang, J., Jensen, B. E., \& Mann, B. L. (1997). Modification and revision of the leadership scale for sport. Journal of sport behavior, 20(1), 105. 